\title{
Tissue-specific differential induction of duplicated fatty acid-binding protein genes by the peroxisome proliferator, clofibrate, in zebrafish (Danio rerio)
}

Ananda B Venkatachalam', Santosh P Lall², Eileen M Denovan-Wright ${ }^{3}$ and Jonathan M Wright ${ }^{1^{*}}$

\begin{abstract}
Background: Force, Lynch and Conery proposed the duplication-degeneration-complementation (DDC) model in which partitioning of ancestral functions (subfunctionalization) and acquisition of novel functions (neofunctionalization) were the two primary mechanisms for the retention of duplicated genes. The DDC model was tested by analyzing the transcriptional induction of the duplicated fatty acid-binding protein (fabp) genes by clofibrate in zebrafish. Clofibrate is a specific ligand of the peroxisome proliferator-activated receptor (PPAR); it activates PPAR which then binds to a peroxisome proliferator response element (PPRE) to induce the transcriptional initiation of genes primarily involved in lipid homeostasis. Zebrafish was chosen as our model organism as it has many duplicated genes owing to a whole genome duplication (WGD) event that occurred 230-400 million years ago in the teleost fish lineage. We assayed the steady-state levels of fabp mRNA and heterogeneous nuclear RNA (hnRNA) transcripts in liver, intestine, muscle, brain and heart for four sets of duplicated fabp genes, fabpla/ fabp 1b.1/fabp 1b.2, fabp7a/fabp7b, fabp10a/fabp10b and fabp11a/fabp11b in zebrafish fed different concentrations of clofibrate.

Result: Electron microscopy showed an increase in the number of peroxisomes and mitochondria in liver and heart, respectively, in zebrafish fed clofibrate. Clofibrate also increased the steady-state level of acox1 mRNA and hnRNA transcripts in different tissues, a gene with a functional PPRE. These results demonstrate that zebrafish is responsive to clofibrate, unlike some other fishes. The levels of fabp mRNA and hnRNA transcripts for the four sets of duplicated fabp genes was determined by reverse transcription, quantitative polymerase chain reaction (RT-qPCR). The level of hnRNA coded by a gene is an indirect estimate of the rate of transcriptional initiation of that gene. Clofibrate increased the steady-state level of fabp mRNAs and hnRNAs for both the duplicated copies of fabpla/ fabp 1b.1, and fabp7a/fabp7b, but in different tissues. Clofibrate also increased the steady-state level of fabp 10a and fabp 11 a mRNAs and hnRNAs in liver, but not for fabp10b and fabp 116.

Conclusion: Some duplicated fabp genes have, most likely, retained PPREs, but induction by clofibrate is over-ridden by an, as yet, unknown tissue-specific mechanism(s). Regardless of the tissue-specific mechanism(s), transcriptional control of duplicated zebrafish fabp genes by clofibrate has markedly diverged since the WGD event.
\end{abstract}

\footnotetext{
* Correspondence: jmwright@dal.ca

'Department of Biology, Dalhousie University, Halifax, NS B3H 4R2, Canada

Full list of author information is available at the end of the article
} 


\section{Background}

In 1970, Ohno [1] proposed that duplication of individual genes, chromosomal segments or whole genomes plays an important role in genome evolution, provides for increasing organismal complexity and contributes to morphological diversification among vertebrates [2-4]. The role of gene duplicates in generating morphological and functional diversity has been discussed by various researchers (see [5] and references therein). To our knowledge, Ohno [1] was the first to suggest possible fates for duplicated genes by the process of either nonfunctionalization or neofunctionalization. Nonfunctionalization of a duplicated gene occurs due to deleterious mutations accumulating in the protein coding region, leading to gene silencing and subsequent loss of one of the duplicate genes from the genome. Ohno [1] further argued that nonfunctionalization is the common fate of a duplicated gene. Neofunctionalization results from mutations in the protein coding region that gives rise to a novel function for a gene product. If this novel function benefits the organism, the gene will be retained in the genome. With complete genomic DNA sequences becoming increasingly available, it is apparent that a greater proportion of gene duplicates are preserved in genomes than that predicted by Ohno's model [6]. In light of these observations, Force et al. [6], subsequently elaborated by Lynch and Conery [7], proposed the duplication-degeneration-complementation (DDC) model. In the DDC model, subfunctionalization is the process by which the functions of the ancestral gene are subdivided between the duplicated genes. Subfunctionalization in the DDC model was proposed as an alternative mechanism to Ohno's neofunctionalization [1] to explain the high retention rate of duplicated genes in the genome. Force et al. [6], however, did not exclude neofunctionalization, in which one of the duplicated genes acquires a novel function. In the DDC model, subfunctionalization and neofunctionalization occur by either loss or gain of cis-regulatory elements in the promoters of the duplicated genes.

Fatty acid-binding protein $(F A B P)$ genes belong to the multigene family of intracellular lipid-binding protein (iLBP) genes that also includes the cellular retinol-binding protein $(C R B P)$ and the cellular retinoic acid-binding protein $(C R A B P)$ genes [8-12]. To date, eighteen paralogous iLBP genes, including 12 FABPs, 4 CRBPs and 2 CRABPs have been identified in the animal kingdom. No FABP genes have been found in plants or fungi, leading Schaap et al. [9] to suggest that the first FABP gene emerged after the divergence of animals from plants, some 930-1000 million years ago (mya). About 230-400 mya, the iLBP multigene family was further augmented in teleost fishes by a whole genome duplication (WGD) event early in teleost fish lineage [4,13-17]. Based on complementary DNA (cDNA) sequence, gene structure, conserved gene synteny with their mammalian, avian and fish orthologs, and spatio-temporal patterns of expression, we have characterized 12 zebrafish $f a b p$ genes [18-30]. Of these 12 zebrafish fabp genes, eight (four pairs) fabpla/fabp 1b, fabp $7 a /$ fabp $7 b$, fabp 10a/fabp $10 b$ and fabp11a/fabp $11 b$ arose as a result of the teleost fish-specific WGD [23,25,28,29]. One pair of duplicated genes, fabp $1 b .1$ and fabp 1b.2, is tandemly arrayed on chromosome 8 separated by $3.8 \mathrm{~kb}$ of DNA [30]. This duplication, subsequent to the WGD early in the fish lineage, is presumably the result of unequal crossing-over between homologous chromosomes during meiosis. The total number of duplicated genes retained in the zebrafish genome following the WGD event is estimated to be 14-30\% [31,32]. Surprisingly, $73 \%$ of the duplicated $f a b p$ genes have been retained in the zebrafish genome. Only three zebrafish $f a b p$ genes exist as single copies, fabp2, fabp 3 and fabp6. Originally, FABPs were named according to their initial tissue of isolation. This nomenclature has become increasingly confusing as some tissues contain more than one FABP, and some FABPs are found in many tissues. As such, we have chosen to use in this paper the nomenclature proposed by Hertzel and Bernlohr [33] e.g., FABP1, FABP2, etc. Although different $F A B P$ genes exhibit distinct, but sometimes overlapping, tissue-specific patterns of expression, the tertiary structure of $F A B P$ genes and their genomic organization are highly conserved [12,34,35]. Almost all $F A B P / f a b p$ genes, with the exception of the FABP3 gene in desert locust [36], the fabpla gene from zebrafish [25] and fabp11a gene from medaka [37], consist of four exons of comparable coding capacity separated by three introns of varying sizes between paralogous and orthologous FABP/fabp genes in different species $[8,9,38-40]$. Despite extensive studies on the structure of FABPs, binding properties and in vitro lipid transfer mechanisms, their precise physiological role remains elusive. However, several studies [reviewed in 12] have implicated FABPs in myriad cellular processes that include: (1) binding and sequestering of long-chain fatty acids, bile salts and other hydrophobic ligands; (2) transport of these ligands to intracellular compartments for metabolism and energy production; (3) interaction with other enzyme systems and transport proteins; and (4) transport of fatty acids (FAs) to the nucleus to regulate gene transcription via activation of the nuclear receptors, the peroxisome proliferator-activated receptors (PPARs) (see [41] and references therein). Currently, our knowledge of the regulatory elements controlling the expression of the $F A B P$ genes is limited and based mainly on studies of mammalian $F A B P$ genes and one $F A B P$ gene in desert locust [42-46]. Her et al. [47,48] cloned the 5' upstream regions, including the basal promoters, of the zebrafish fabp $10 a$ and fabp 2 genes. They identified a 435 base pairs (bp) region with two distinct liver regulatory elements in the liver-basic fatty acid-binding protein $(f a b p 10 a)$ gene, 
which is sufficient to modulate liver regional expression in transgenic zebrafish [47]. A 192 bp region was identified in the 5 upstream region of the intestinal-type fatty acidbinding protein $(f a b p 2)$ gene sufficient to direct intestinespecific expression in zebrafish larval development [48]. Neither of these studies provided insight into why both duplicated fabp10 genes, fabp10a and fabp10b, were retained in the zebrafish genome, or why a copy of the duplicated $f a b p 2$ gene was lost from the zebrafish genome following the WGD in the teleost fishes.

In previous studies, we have shown that transcriptional initiation of only one copy in each of three sets of duplicated fabp genes of zebrafish, fabpla/fabp1b.1/fabp1b.2, $f a b p 7 a / f a b p 7 b$ and $f a b p 11 a / f a b p 11 b$, is modulated by dietary FAs in a given tissue [49]. Since FAs are known to be ligands of PPARs that leads to transcriptional up-regulation of target genes, we anticipated that the transcriptional modulation of $f a b p$ genes in various tissues of zebrafish fed different FAs might be mediated by PPARs. The goal of the present research was, therefore, to investigate whether the duplicated $f a b p$ genes in zebrafish are differentially regulated by PPAR, by using clofibrate, a PPAR agonist. Clofibrate has been used extensively to investigate the regulation of gene transcription in vertebrates, owing to its specific binding with PPAR $\alpha$, and to a lesser extent to PPAR $\gamma$, and its effect on the transcription of specific genes involved in lipid metabolism [50-57]. We assayed the steady-state levels of fabp mRNA and heterogeneous nuclear RNA (hnRNA) transcripts for four sets of duplicated fabp genes, fabpla/ fabp1b.1/fabp1b.2, fabp7a/fabp7b, fabp10a/fabp10b and fabp 11a/fabp $11 b$ in zebrafish fed different concentrations of clofibrate to determine if clofibrate induced transcriptional initiation of only one of a pair of duplicated fabp genes. We show here, however, that clofibrate induced the transcriptional initiation of both pairs of some duplicated $f a b p$ genes in zebrafish, but the induction is differentially regulated by an, as yet, unknown tissue-specific mechanism(s).

\section{Results and discussion}

Zebrafish is responsive to the peroxisome proliferator, clofibrate

Peroxisome proliferators, such as clofibrate, are known to cause a marked proliferation of peroxisomes in the hepatocytes of animals [58-65]. Proliferation of peroxisomes is also associated with a predictable pleiotropic response, characterized by hepatomegaly, and the increased steadystate level of mRNAs coding for peroxisomal enzymes
A

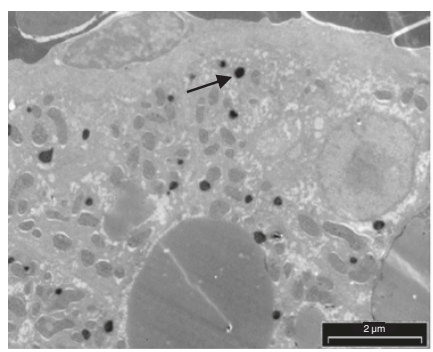

B

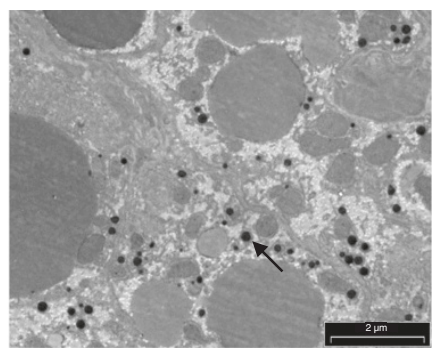

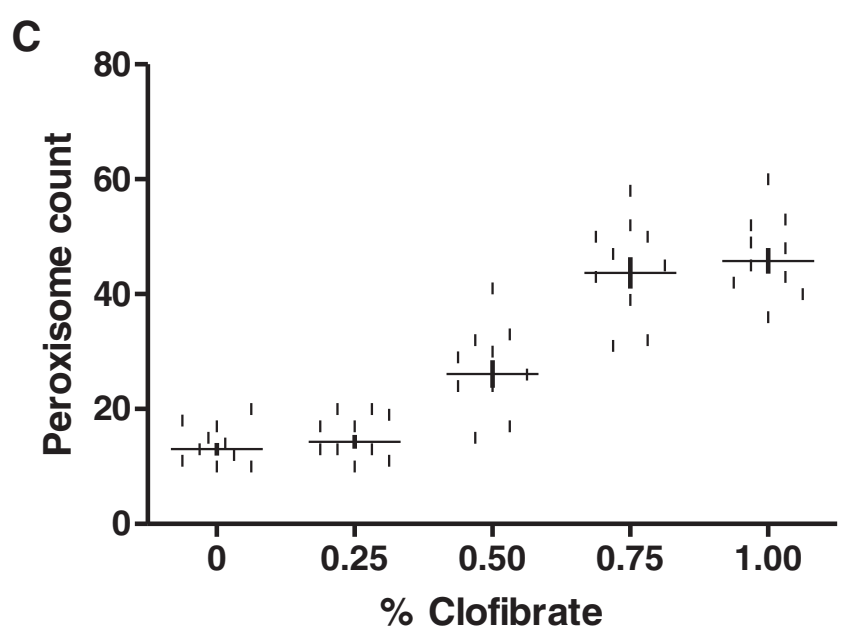

Figure 1 Electron micrographs of hepatocytes of zebrafish after clofibrate treatment. Staining of peroxisomes in the hepatocytes of zebrafish fed $0 \%$ clofibrate (A) and 1.00\% clofibrate (B). Number of peroxisome per field of view in liver increased with increasing concentration of clofibrate fed zebrafish (C). Arrows point to peroxisomes. Bar $=2 \mu \mathrm{m}$. 
[61]. In this study, we first wished to determine if clofibrate acts as a peroxisome proliferator in zebrafish as vertebrate species show different responses to clofibrate as assayed by peroxisome proliferation or induction of steady-state transcript levels for several clofibrateresponsive genes. Rats and mice are more responsive to clofibrate than hamsters and humans [66,67], while some fish, such as medaka and rainbow trout, show little response [51], and sea bass is essentially refractory to clofibrate treatment [68]. The number of peroxisomes was higher in hepatocytes of zebrafish fed $\geq 0.75 \%$ clofibrate (Figure 1B) compared to livers of zebrafish not fed clofibrate (Figure 1A). The number of peroxisomes in liver increased 4 -fold in zebrafish fed $\geq 0.75 \%$ clofibrate compared to the control (Figure 1C). The peroxisomal numbers in intestine did not change with clofibrate treatment, whereas, in other tissues like muscle, brain and heart, we could not observe any peroxisomes (data not shown). Previous studies in rats and mice fed clofibrate showed an increase in the number of mitochondria in the liver [69-71]. In this study, zebrafish fed $\geq 0.75 \%$ clofibrate showed an increase in the number of mitochondria only in heart cells (Figure 2B) compared to the control (Figure 2A). The number of mitochondria in heart cells increased 2-fold in zebrafish fed $\geq 0.75 \%$ clofibrate compared to the control
(Figure 2C). The mitochondrial number in other tissues (liver, intestine, muscle and brain) examined did not change in zebrafish fed clofibrate.

Clofibrate has been widely used in vertebrates to activate PPAR $\alpha$, and in some instances PPAR $\gamma$, to induce transcriptional initiation of genes involved in lipid homeostasis, such as the acyl-CoA oxidase 1 (Acox1) gene, a gene that contains a peroxisome proliferator response element (PPRE) $[52,65,72,73]$. In rats, transcriptional initiation of PPAR $\alpha$-responsive genes are upregulated in the liver, moderately up-regulated in the small intestine and to a lesser extent up-regulated in other tissues, such as skeletal muscle, heart and kidney by clofibrate [56]. The level of Acox 1 mRNA in liver, heart, kidney, duodenum and jejunum is increased in rats fed clofibrate compared to controls, but not in ileum and brain [56]. Clofibrate was also shown to increase the level of Acox 1 mRNA in liver of chicken [54], liver and adipose tissue of pigs [55], hepatocytes of rainbow trout [63] and liver of rats [64]. In this study, the steady-state level of acox1 mRNA increased 3-fold in liver (Figure 3A), 3-fold in intestine (Figure 3B), 2-fold in muscle (Figure 3C) and 2.5-fold in heart (Figure 3D) of zebrafish fed $\geq 0.50 \%$ clofibrate compared to zebrafish fed $<0.50 \%$ clofibrate.
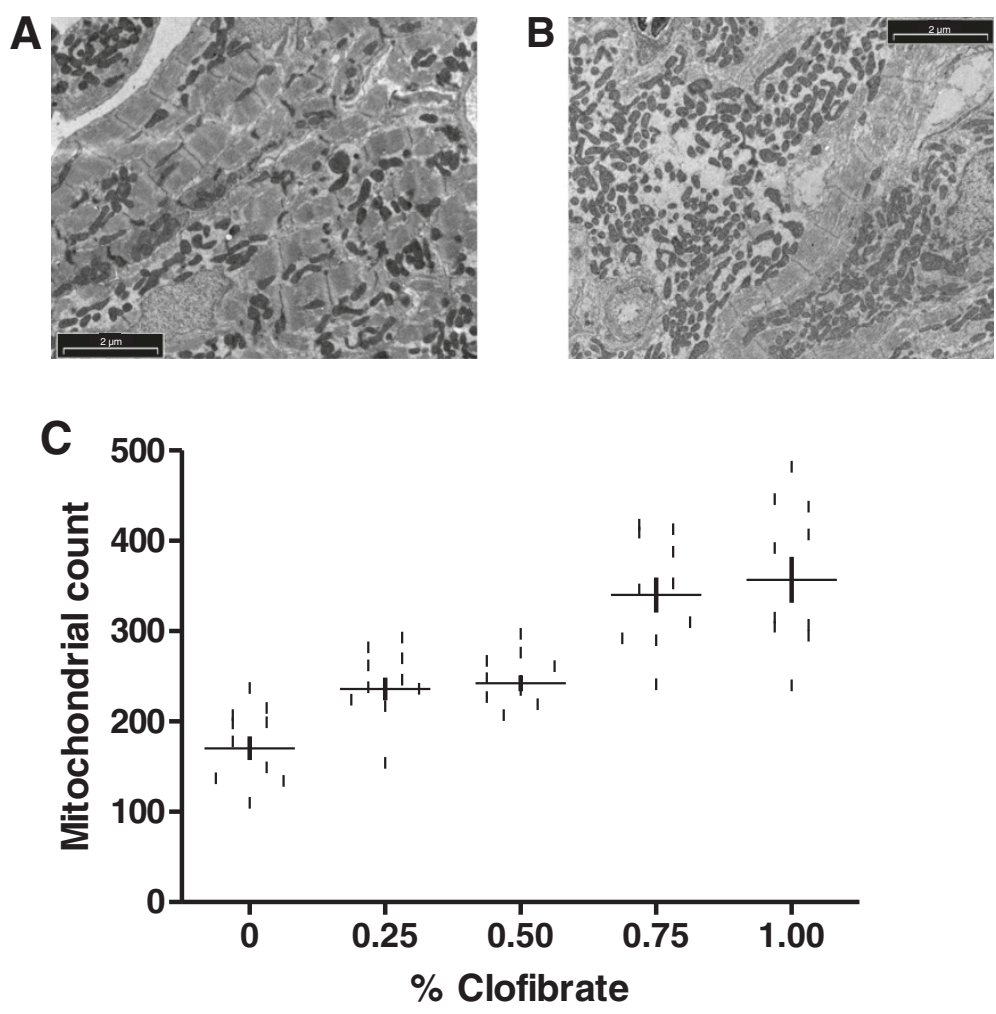

Figure 2 Electron micrographs of heart cells of zebrafish after clofibrate treatment. Mitochondria in the heart cells of zebrafish fed $0 \%$ clofibrate (A) and 1.00\% clofibrate (B). Number of mitochondria per field of view in heart increased with increasing concentration of clofibrate fed zebrafish (C). Bar $=2 \mu \mathrm{m}$. 

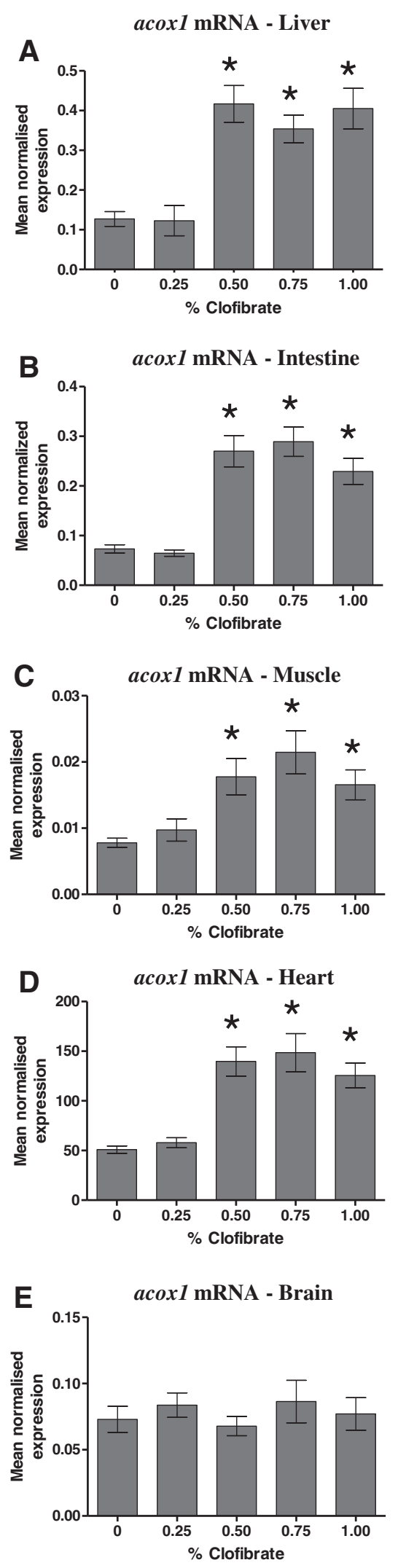

Figure 3 (See legend on next page.)
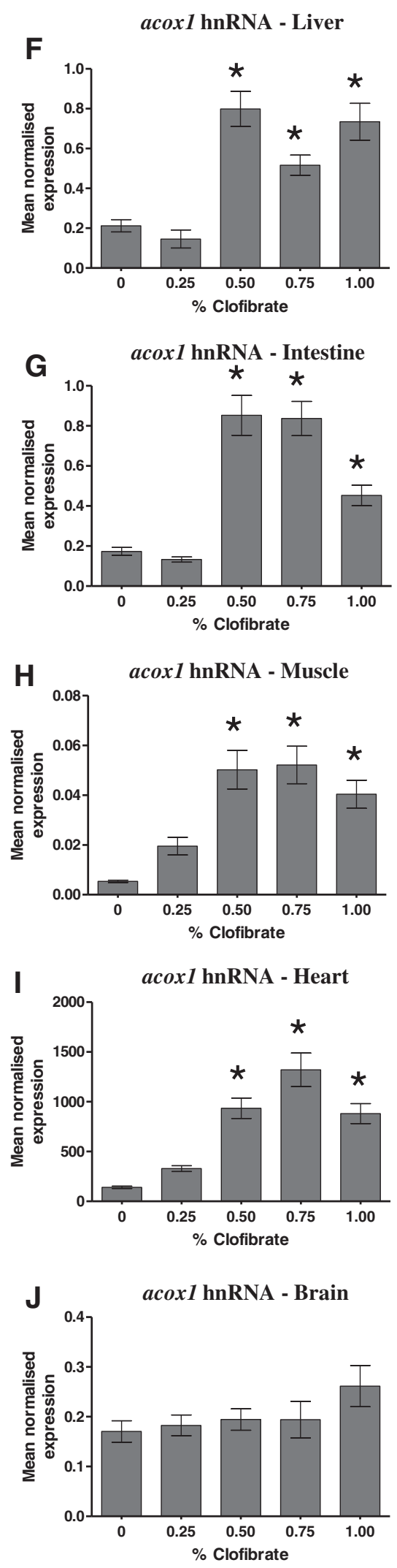
(See figure on previous page.)

Figure 3 The steady-state level of acox1 mRNA and hnRNA in various tissues of zebrafish fed clofibrate. The level of mRNA and hnRNA of the acoxl gene in liver $(\mathbf{A}, \mathbf{F})$, intestine $(\mathbf{B}, \mathbf{G})$, muscle $(\mathbf{C}, \mathbf{H})$, heart $(\mathbf{D}, \mathbf{I})$ and brain $(\mathbf{E}, \mathbf{J})$ was determined by RT-qPCR using gene-specific primers. The steady-state level of acox 1 transcripts was normalized to the steady-state level of rp/13a transcripts in the same sample. Data are presented as the mean ratio \pm S.E.M. Significant differences $(p<0.05)$ in the relative steady-state level of acox $1 \mathrm{mRNA}$ and hnRNA between zebrafish $[n=12$, (male $=6$, female $=6)$ ] fed different concentrations of clofibrate compared to zebrafish not fed clofibrate are indicated by an asterisk.

To determine if the increased levels of acox 1 mRNA transcripts by clofibrate in various tissues was due to an increased rate of transcriptional initiation, we assayed the steady-state level of hnRNA coded by the acox 1 gene. The level of hnRNA for a given gene is an indirect estimate of the rate of transcriptional initiation for that gene as the processing of hnRNA to mRNA occurs rapidly [74]. Zebrafish acox1 hnRNA increased 2.5-fold in liver (Figure 3F), 2-fold in intestine (Figure 3G), 8-fold in muscle (Figure 3H) and 4-fold in heart (Figure 3I) of fish fed $\geq 0.50 \%$ clofibrate compared to zebrafish fed $<0.50 \%$ clofibrate indicating an increase of transcriptional initiation of the acox 1 gene in these tissues. In brain, acox 1 mRNA and hnRNA levels did not change in zebrafish fed clofibrate (Figure 3E, 3J). The lack of affect on the level of acox 1 transcripts in the brain of zebrafish fed clofibrate may be due to: (i) clofibrate does not cross the blood brain barrier, or (ii) if clofibrate does cross the blood brain barrier, the acox 1 gene is not induced by clofibrate in the brain of zebrafish. The increased number of peroxisomes and mitochondria in the liver and heart, respectively, and the induction of the transcriptional initiation of the acox 1 gene by clofibrate in liver, intestine, muscle and heart is compelling evidence that zebrafish is responsive to this peroxisome proliferator, like many other vertebrates [58-72,75].

\section{Tissue-specific up-regulation of zebrafish fabp transcription by clofibrate}

Some mammalian FABP genes are induced by various FAs and peroxisome proliferators, and molecular mechanisms for their induction have been proposed [46,76-80]. FABPs transport long-chain FAs from the cytoplasm to the nucleus $[80,81]$. Inside the nucleus, FABPs transfer their long-chain FAs to nuclear receptors, such as PPAR $\alpha$ and PPAR $\gamma$ [82-84]. Dietary long chain FAs and peroxisome proliferators activate these nuclear receptors, and once activated, these nuclear receptors form heterodimers with retinoic-acid receptors (RAR) or retinoid $\mathrm{X}$ receptors (RXR) (e.g., PPAR-RAR and PPAR-RXR), which in turn bind to response elements in $F A B P$ genes, and thereby, stimulate initiation of transcription [85-91]. Previous reports have shown that FAs and peroxisome proliferators increase the steady-state level of $L-F A B P(F A B P 1)$ and I-FABP $(F A B P 2)$ gene transcripts in the mammalian liver and small intestine $[43,76,77,79,92,93]$. Peroxisome proliferators also increase the transcriptional activity of $A-F A B P$ (FABP4) in adipocytes of mice [46,84].

\section{Up-regulation of transcription of duplicated zebrafish fabp 1 genes by clofibrate}

In this study, the steady-state level of fabpla mRNA increased 1.5-fold in the intestine of zebrafish fed $0.50 \%$ and $0.75 \%$ clofibrate (Figure $4 \mathrm{~A}$ ) and increased 4-fold in muscle of zebrafish fed $0.50 \%$ clofibrate compared to zebrafish not fed clofibrate (Figure 4E). In heart cells of zebrafish fed $\geq 0.75 \%$ clofibrate, fabp 1b.1 mRNA increased 2-fold compared to zebrafish not fed clofibrate (Figure 4J). To determine if the increased levels of fabpla mRNAs was the result of transcriptional initiation, we assayed the levels of hnRNA for these fabp genes in various tissues of zebrafish. The steady-state level of fabpla hnRNA increased 6-fold in intestine of zebrafish fed $\geq 0.50 \%$ clofibrate (Figure $4 \mathrm{D}$ ) and $>5$-fold in muscle of zebrafish fed $0.50 \%$ clofibrate (Figure $4 \mathrm{H}$ ). In zebrafish fed $\geq 0.50 \%$ clofibrate, the level of fabp $1 b .1$ hnRNA in heart increased 3-fold compared to zebrafish fed the control diet. (Figure 4L). The levels of fabpla mRNA in heart (Figure 4I), fabp1b.1 mRNA in intestine (Figure 4B), fabp1b.1 mRNA in muscle (Figure 4F), fabp 1b.2 mRNA in intestine (Figure 4C), fabp $1 b .2$ mRNA in muscle (Figure 4G) and fabp1b.2 mRNA in heart (Figure $4 \mathrm{~K}$ ) remained unchanged in zebrafish fed clofibrate.

\section{Up-regulation of transcription of zebrafish fabp7 genes by clofibrate}

Duplicated copies of zebrafish $f a b p 7$ (fabp7a and $f a b p 7 b)$ exhibited distinct tissue-specific patterns of upregulation by clofibrate of levels of both mRNA and hnRNA (Figure 5). fabp7a mRNA increased $>7$-fold in liver of zebrafish fed $0.50 \%$ clofibrate (Figure 5A) and $>2$-fold in intestine of zebrafish fed $1.00 \%$ clofibrate (Figure 5D), while fabp $7 b$ mRNA levels increased 6-fold only in muscle of zebrafish fed $\geq 0.50 \%$ clofibrate compared to zebrafish not fed clofibrate (Figure $5 \mathrm{H}$ ).

The increase in the mRNA levels of zebrafish fabp7 genes correlated with the increase in the levels of their hnRNA. fabp7a hnRNA increased $>3$-fold in liver of zebrafish fed $0.50 \%$ clofibrate (Figure $5 \mathrm{C}$ ) and 7 -fold in intestine of zebrafish fed $\geq 0.75 \%$ clofibrate (Figure $5 \mathrm{~F}$ ), 


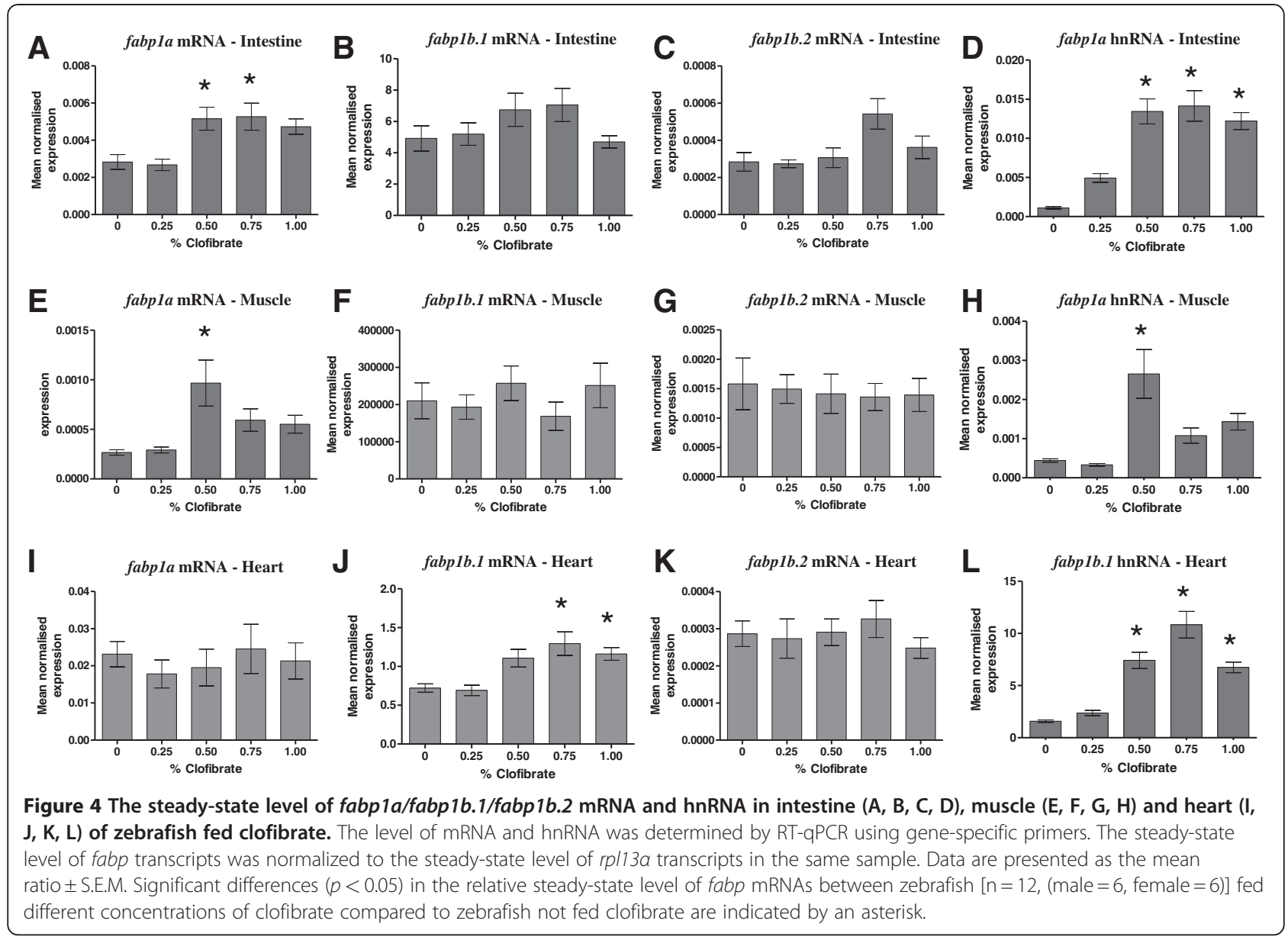

while fabp $7 b$ hnRNA increased 6-fold in muscle of zebrafish fed $\geq 0.50 \%$ clofibrate (Figure $5 \mathrm{I}$ ) compared to control zebrafish. No change was observed in the levels of fabp $7 b$ mRNA transcripts in liver (Figure $5 \mathrm{~B}$ ) and intestine (Figure 5E), and fabp7a mRNA in muscle (Figure 5G) in zebrafish fed clofibrate.

\section{Up-regulation of zebrafish fabp 10 gene transcription by clofibrate}

The steady-state level of fabp 10a mRNA increased $>2$ fold in liver of zebrafish fed $0.50 \%$ clofibrate compared to control (Figure 6A), whereas the level of fabp $10 b$ mRNA (Figure 6B) did not change in the liver of zebrafish fed clofibrate. A 3-fold increase of fabp 10a hnRNA mirrored the increase of mRNA coded by this gene in liver of zebrafish fed $1.00 \%$ clofibrate compared to control zebrafish (Figure 6C).

\section{Up-regulation of zebrafish fabp 11 gene transcription by clofibrate}

The steady-state level of fabp11a mRNA (Figure 6D) increased 3 -fold in liver of zebrafish fed $\geq 0.75 \%$ clofibrate compared to control, but the steady-state level of fabp $11 b$ transcripts (Figure 6E) did not change in the liver of zebrafish fed clofibrate. Similarly, fabp 11a hnRNA increased $>4$-fold in liver of zebrafish fed $\geq$ $0.75 \%$ clofibrate compared to control (Figure 6F). No difference in the steady-state level of any fabp mRNA and hnRNA assayed was observed between male and female zebrafish (data not shown).

\section{Conclusion}

We report here that zebrafish fed clofibrate exhibited distinct patterns of up-regulation of the steady-state level of mRNAs of duplicated fabp genes (Table 1). None of the levels of $f a b p$ mRNA transcripts assayed changed in the brain of zebrafish fed clofibrate (data not shown). Furthermore, changes in the levels of mRNA for a specific $f a b p$ gene were directly correlated with changes in the steady-state level of hnRNA for that particular fabp gene indicating that clofibrate induced transcriptional initiation of zebrafish fabp genes (Table 1). Clofibrate induction of some zebrafish fabp genes appears, however, to be controlled by a tissue-specific mechanism(s), as induction of the steady-state level of fabp mRNAs and hnRNAs by clofibrate was seen for both duplicated 


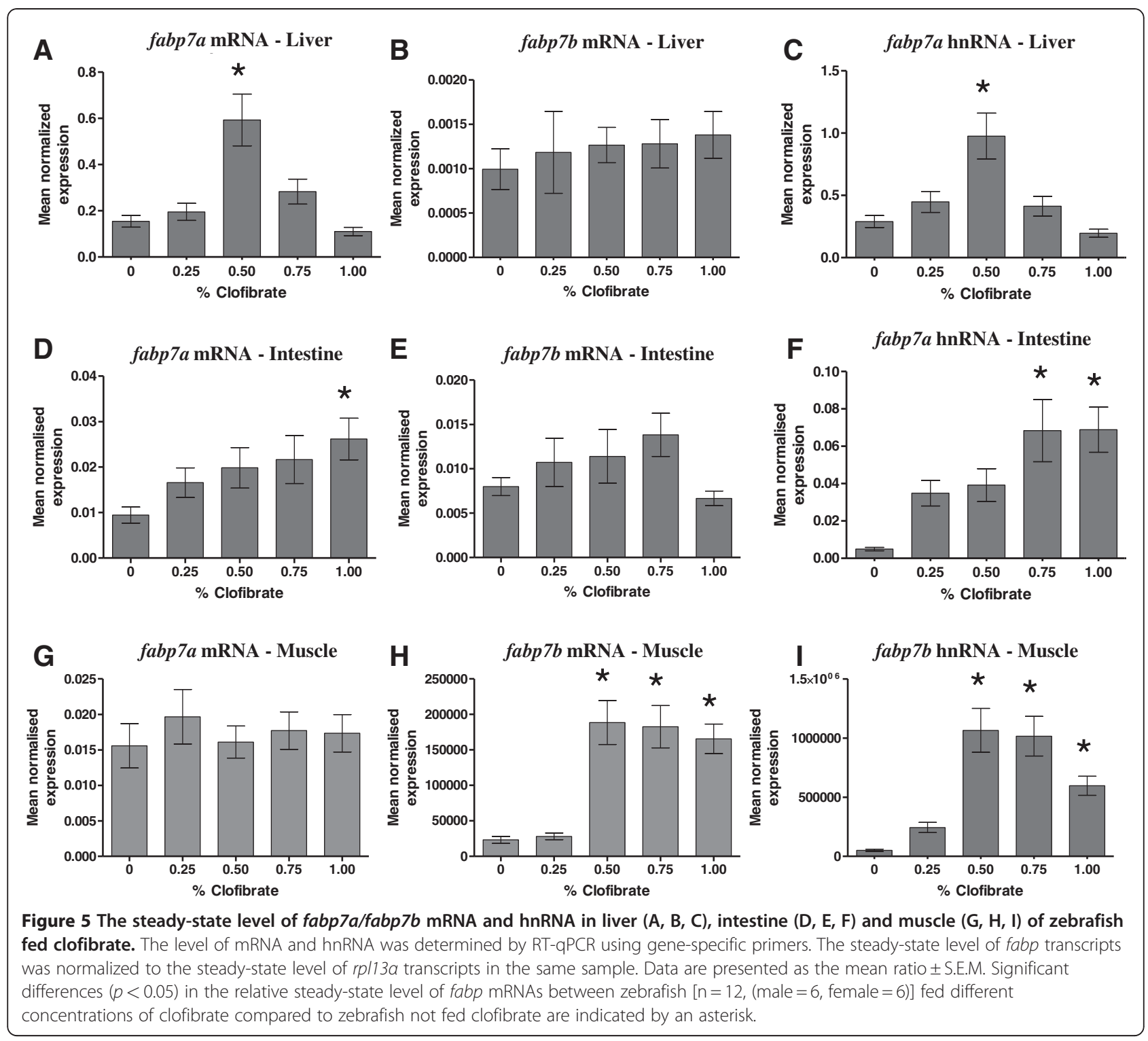

copies of $f a b p 1 a / f a b p 1 b .1$, and $f a b p 7 a / f a b p 7 b$, but in different tissues. Clofibrate also increased the steadystate level of fabp10a and fabp 11a mRNAs and hnRNAs in liver, but not for fabp $10 b$ and fabp $11 b$.

Based on in silico analyses, we found that most zebrafish fabp genes contain putative PPREs within 7 kilobase pairs $(\mathrm{kb})$ of DNA upstream of the transcriptional initiation site of each fabp gene (data not shown). Since functional PPREs that activate gene transcription via peroxisome proliferators have also been found in introns $[73,94]$, we screened the intronic sequences of each of the zebrafish $f a b p$ genes described in this paper for PPREs. Many of these fabp genes contained putative PPREs in their introns (data not shown). While in silico analyses can be very useful in determining the direction of future experimental work, the results of in silico analyses must be interpreted cautiously. To illustrate this cautionary point, in silico analysis of the rat peroxisomal thiolase $B$ gene identified a putative PPRE in the promoter region of this gene that did not bind PPAR $\alpha$ in vitro, but subsequent studies showed that a functional PPRE in intron 3 of this gene did bind an activated PPAR $\alpha$ in vitro [94]. To demonstrate that the putative PPREs we have found by in silico analysis in the various zebrafish $f a b p$ genes are indeed functional will require studies involving deletion of PPREs and/or site directed mutation of putative PPRE sequences in the fabp promoters and introns to demonstrate loss of function in various cell culture lines and transgenic zebrafish. If functional PPREs are identified in the zebrafish $f a b p$ genes, the most parsimonious explanation of the tissuespecific differential induction of transcriptional initiation 


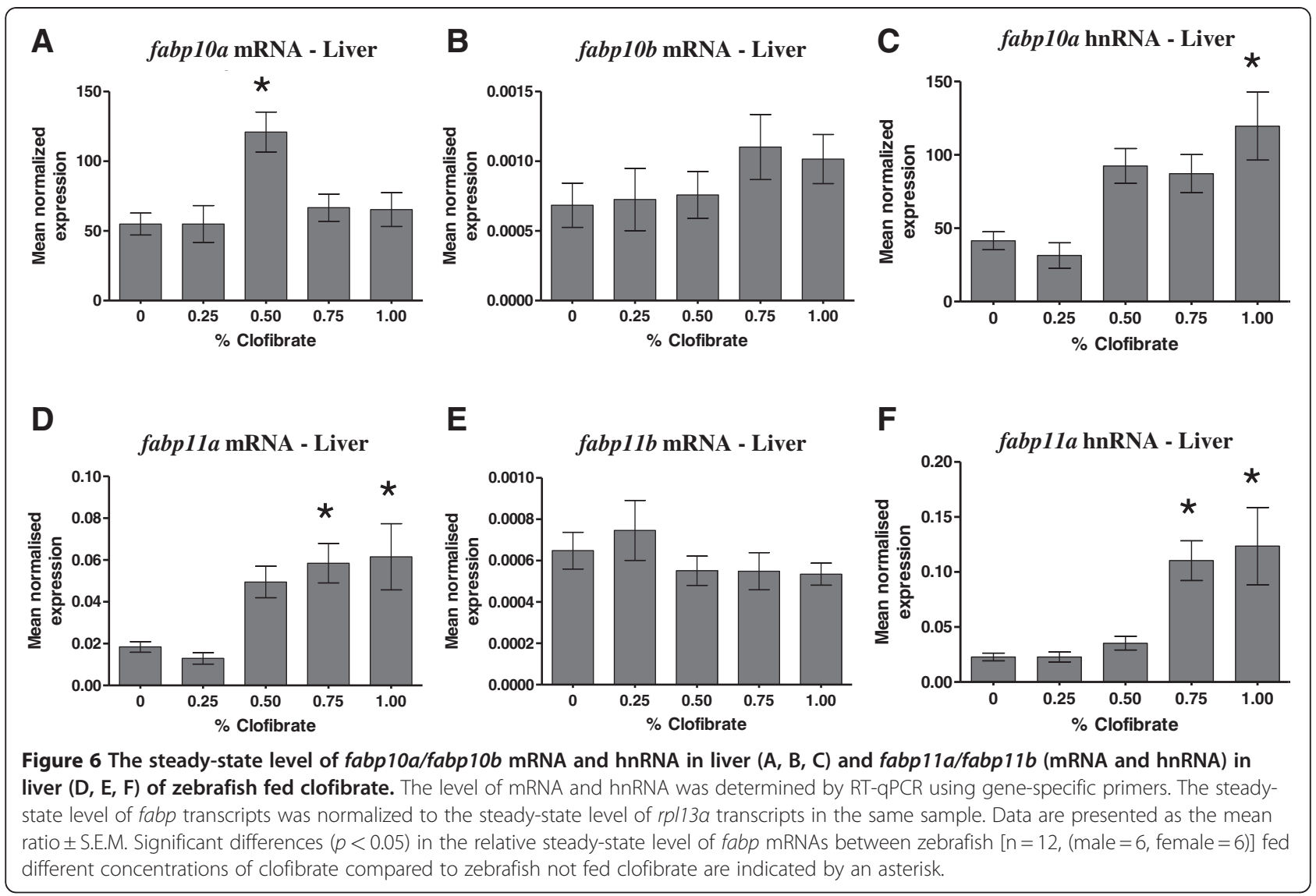

of the duplicated zebrafish fabpla/fabp $1 b .1$ and $f a b p 7 a /$ $f a b p 7 b$ genes by clofibrate is that both duplicated copies of these gene have retained a functional PPRE, but that induction by clofibrate is over-ridden by an, as yet, unknown tissue-specific mechanism(s). An alternative explanation is that induction of $f a b p$ transcriptional

Table 1 Steady-state levels of specific mRNA and hnRNA of fabp genes increased in tissues of zebrafish after clofibrate treatment

\begin{tabular}{llllll}
\hline Gene & Liver & Intestine & Muscle & Heart & Brain \\
\hline acox1 & + & + & + & + & - \\
fabp1a & - & + & + & - & - \\
fabp1b.1 & - & - & - & + & - \\
fabp1b.2 & - & - & - & - & - \\
fabp7a & + & + & - & - & - \\
fabp7b & - & - & + & - & - \\
fabp10a & + & - & - & - & - \\
fabp10b & - & - & - & - & - \\
fabp11a & + & - & - & - & - \\
fabp11b & - & - & - & - & - \\
\hline
\end{tabular}

+ , increase relative to control.

- , no change relative to control. initiation by clofibrate is mediated via an indirect mechanism wherein the induction of fabp genes occurs by an intermediate or "upstream" gene activated by PPAR coding for a transcription factor, which in turn activates zebrafish $f a b p$ genes. Again, however, this indirect induction of fabp gene transcription by clofibrate-activated PPAR must be mediated by an over-riding tissue-specific mechanism(s). Whether clofibrate-induced transcription of zebrafish fabp genes is the result of clofibrateactivated PPAR directly at a fabp PPRE or indirectly via an "upstream" gene coding for a regulatory protein, the regulatory DNA elements in the duplicated $f a b p$ genes have certainly diverged markedly since the WGD event 230-400 million years ago [4,13-17], thereby supporting the DDC model [6,7] for the retention of these duplicated $f a b p$ genes in the zebrafish genome.

\section{Materials and methods}

Experimental diet and zebrafish husbandry

Experimental diets containing five different concentrations $(0,0.25,0.50,0.75$ and $1.00 \% \mathrm{w} / \mathrm{w})$ of clofibrate (Sigma-Aldrich, Oakville, Ontario, Canada) were formulated (Table 2). Clofibrate concentrations and basic feed formulation were based on previous dietary studies [57,95-97] and the United States National Research 
Table 2 Composition of diets (\% by weight)

\begin{tabular}{|c|c|c|c|c|c|}
\hline Ingredients & $0 \%$ clofibrate diet & $0.25 \%$ clofibrate diet & $0.50 \%$ clofibrate diet & $0.75 \%$ clofibrate diet & $1.00 \%$ clofibrate diet \\
\hline Vitamin free casein $^{a}$ & 33 & 33 & 33 & 33 & 33 \\
\hline Wheat gluten ${ }^{\mathrm{b}}$ & 10 & 10 & 10 & 10 & 10 \\
\hline Gelatin $^{a}$ & 4 & 4 & 4 & 4 & 4 \\
\hline Corn oil ${ }^{c}$ & 4 & 4 & 4 & 4 & 4 \\
\hline Fish oil $^{d}$ & 4 & 4 & 4 & 4 & 4 \\
\hline Corn starch $^{e}$ & 33 & 33 & 33 & 33 & 33 \\
\hline Celufil $^{1}$ & 8.00 & 7.75 & 7.50 & 7.25 & 7.00 \\
\hline Vitamin mix ${ }^{f}$ & 1.30 & 1.30 & 1.30 & 1.30 & 1.30 \\
\hline Mineral mix ${ }^{g}$ & 1 & 1 & 1 & 1 & 1 \\
\hline Betaine $^{h}$ & 1.50 & 1.50 & 1.50 & 1.50 & 1.50 \\
\hline DL-Methionine ${ }^{a}$ & 0.20 & 0.20 & 0.20 & 0.20 & 0.20 \\
\hline Clofibrate $^{i}$ & 0 & 0.25 & 0.50 & 0.75 & 1.00 \\
\hline Total & 100 & 100 & 100 & 100 & 100 \\
\hline
\end{tabular}

a US Biochemical. (Cleveland, OH, USA).

b Dover Mills Ltd. (Halifax, NS, Canada).

c Sobeys Inc. (Halifax, NS, Canada).

d Corey Feeds Ltd. (Fredericton, NB, Canada).

e National Starch and Chemical Co. (Bridgewater, NJ, USA)

${ }^{f}$ Vitamin added to supply the following (per kg diet): vitamin A, 8000 IU; vitamin D3, 4000 IU; vitamin E, 300 IU; menadione sodium bisulfite, 40 mg; Thiamine $\mathrm{HCl}$ $50 \mathrm{mg}$; riboflavin, $70 \mathrm{mg}$; d-Ca pantothenate, $200 \mathrm{mg}$; biotin, $1.5 \mathrm{mg}$; folic acid, $20 \mathrm{mg}$; vitamin B12, $0.15 \mathrm{mg}$; niacin, $300 \mathrm{mg}$; pyridoxine HCl, $20 \mathrm{mg}$; ascorbic acid, $300 \mathrm{mg}$; inositol, $400 \mathrm{mg}$; choline chloride, $2000 \mathrm{mg}$; butylated hydroxy toluene, $15 \mathrm{mg}$; butylated hydroxy anisole, $15 \mathrm{mg}$.

${ }^{\mathrm{g}}$ Mineral added to supply the following (per kg diet): manganous sulphate (32.5\% Mn), $40 \mathrm{mg}$; ferrous sulphate (20.1\% Fe), $30 \mathrm{mg} ;$ copper sulphate ( $25.4 \%$ Cu),

$5 \mathrm{mg}$; zinc sulphate $(22.7 \% \mathrm{Zn}), 75 \mathrm{mg}$; sodium selenite $(45.6 \% \mathrm{Se}), 1 \mathrm{mg}$; cobalt chloride ( $24.8 \% \mathrm{Co}), 2.5 \mathrm{mg}$; sodiumfluoride ( $42.5 \% \mathrm{~F}), 4 \mathrm{mg}$

${ }^{h}$ Betaine anhydrous ( $96 \%$ feed grade). (Finnfeeds, Finland). ' Sigma-Aldrich Inc. (St. Louis, MO, USA).

Council's nutrient requirement recommendations for warm-water fishes [95]. The dry ingredients were mixed using a Hobart mixer for $20 \mathrm{~min}$. Choline chloride was dissolved in distilled water and clofibrate mixed in corn oil prior to addition to dry ingredients. Boiling water was added to the dry ingredients to make wet dough $(40 \% \mathrm{v} / \mathrm{v})$. The dough was spread on tray and freezedried for 36-48 h. The freeze-dried diet was then passed through a $0.8 \mathrm{~mm}$ mesh to yield particles of less than $800 \mu \mathrm{m}$, which were then stored at $-20^{\circ} \mathrm{C}$.

To reduce genetic variance, four female and two male adult zebrafish of the AB strain [98], obtained from the Aquatron at Dalhousie University, were bred in a single tank to produce embryos. Embryos, larvae and adult fish were maintained in aerated water at $28.5^{\circ} \mathrm{C}$ on a $14 \mathrm{~h}$ light and $10 \mathrm{~h}$ dark cycle [99]. One hundred and fifty day-old zebrafish were acclimatized in $35 \mathrm{~L}$ aquaria for four weeks prior to feeding fish diets containing clofibrate. Three replicates of five different dietary groups of fish were distributed in 15 tanks in a randomized complete block design. Each tank contained 15 zebrafish. Fish in each tank were maintained under the same light intensity and photoperiod. After acclimatization for a week, fish were fed the experimental diets twice a day to satiation. At the end of four weeks, fish were anaesthetized by immersion in a solution of $0.20 \%(\mathrm{v} / \mathrm{v})$ MS-222 prior to tissue dissection. Dissection of fish was done on ice. From each fish, liver, intestine, muscle, brain and heart were removed. All experimental protocols were approved by the Dalhousie University Committee on Laboratory Animals in accordance with the recommendations of the Canadian Council on Animal Care.

\section{Electron microscopy to visualize peroxisomes and mitochondria}

Tissue samples (liver, intestine, muscle, brain and heart) from $0,0.25,0.50,0.75$ and $1.00 \%(\mathrm{w} / \mathrm{w})$ clofibrate-fed fish were dissected and transferred to centrifuge tubes containing $2 \%$ glutraldehyde fixative (osmolarity 300 mOsm) for 30-40 min on ice [100]. The tissue samples were subjected to three 10-minute washes in $0.1 \mathrm{M}$ cacodylate buffer. The samples were transferred to $0.1 \mathrm{M}$ Tris- $\mathrm{HCl}$ buffer and washed twice for $10 \mathrm{~min}$. The samples were pre-incubated in $1 \%$ diaminobenzidine (DAB) solution for $30 \mathrm{~min}$ at $37^{\circ} \mathrm{C}$ with shaking. Ten $\mu \mathrm{l}$ of $30 \%$ hydrogen peroxide solution was added and the samples were incubated for $20-30 \mathrm{~min}$ at $37^{\circ} \mathrm{C}$ with shaking. Tissues were washed in $0.1 \mathrm{M}$ TBS for $10 \mathrm{~min}$ and transferred to centrifuge tubes and subjected to three 10-minute washes with $0.1 \mathrm{M}$ cacodylate buffer at room temperature [101]. Finally, the tissues were post-fixed in $1 \%$ osmium in $0.1 \mathrm{M}$ cacodylate buffer for $1 \mathrm{~h}$ at $4^{\circ} \mathrm{C}$ and washed in filtered, deionized $\mathrm{H}_{2} \mathrm{O}$ for $15 \mathrm{~min}$. Tissues were dehydrated for transmission electron microscopy, infiltrated overnight and later embedded in epon resin [102]. Ten electron microscopy images of tissues for peroxisomes and 
mitochondria were counted in tissues of adult zebrafish fed different concentrations of clofibrate.

\section{RNA isolation, CDNA synthesis and RT-qPCR}

Total RNA was extracted from adult zebrafish tissues using TRIzol (Invitrogen, Carlsbad, CA, USA) according to the protocol recommended by the supplier. The quality and quantity of extracted RNA was assessed by agarose gel-electrophoresis and spectrophotometry at $260 \mathrm{~nm}$, respectively. cDNA was synthesized from mRNA using an oligo (dT) primer according to the manufacturer's protocol for the omniscript RT kit (Qiagen, Mississauga, Canada). cDNA was synthesized from hnRNA using random hexamers. Primer sequences for the quantification of mRNA and hnRNA encoded by different $f a b p$ genes and their annealing temperature (AT) for primer pairs of each $f a b p$ gene during PCR are shown in Table 3. To assay specific hnRNAs, one primer was complementary to an intronic sequence, while the other was complementary to an exonic sequence. acox 1 , a gene known to be induced by clofibrate in many organisms [52,72] was used as a positive control.

Amplification of cDNA samples and DNA standards was carried out using the QuantiTect SYBR Green PCR
Kit (Qiagen, Mississauga, Ontario, Canada) following the manufacturer's instructions. For thermal cycling and fluorescence detection, a Rotor-Gene 3000 system (Corbett Research, Sydney, Australia) was used. PCR conditions were: initial hold for $15 \mathrm{~min}$ at $95^{\circ} \mathrm{C}$ followed by 40 cycles of $15 \mathrm{~s}$ denaturation at $94^{\circ} \mathrm{C}, 20 \mathrm{~s}$ annealing of primers at different temperatures depending on the primer pairs (see Table 3), and $30 \mathrm{~s}$ of elongation at $72^{\circ} \mathrm{C}$. Following completion of the PCR cycles, the melting temperature of the PCR product was determined as an indication that total fluorescence was derived from a single gene-specific product. Fluorescence was measured following each cycle. The copy number of mRNA and hnRNA for each fabp gene was determined using the standard curves as explained by Bustin et al. [103]. As negative controls, reverse transcriptase was omitted from cDNA synthesis reactions for each sample and these controls were subjected to quantitative PCR. To determine the relative steady-state level of $f a b p$ mRNA and hnRNA transcripts in each tissue, the absolute copy number of $f a b p$ mRNA and hnRNA transcripts was divided by the copy number of ribosomal protein large subunit 13 $\alpha(r p l 13 \alpha)$ [104] mRNA and hnRNA transcripts in each sample.

Table 3 Primer sequences used for RT-qPCR

\begin{tabular}{|c|c|c|c|c|}
\hline Gene symbol & Entrez Gene ID & Forward primer $5^{\prime} \rightarrow 3^{\prime}$ & Reverse primer $5^{\prime} \rightarrow 3^{\prime}$ & $A T^{a}$ \\
\hline \multicolumn{5}{|c|}{ mRNA quantification } \\
\hline fabpla & 791610 & TAAGCTGACAGCGTITGTGAAGGG & AGATGCGTCTGCTGATCCTCTTGT & 60.0 \\
\hline fabp1b.1 & 554095 & AAGCTGAAGGTGGTGCTGAACA & CACGTTTGCTGATGCGCTTGTA & 59.0 \\
\hline fabp $1 b .2$ & EB880179 & TGCCGTTCTCTGGGAAGTTTGAGT & TGACTTTGTCTCCGCTCAGCATCT & 61.0 \\
\hline fabp7a & 58128 & TGTGCCACTTGGAAACTGGTTGAC & AACATTGCCTACTTGCCTGGTAGG & 60.0 \\
\hline fabp $7 b$ & 407736 & AAACCACTGCTGATGACCGACACT & AGTGGTCTCTITCCCATCCCACTT & 61.0 \\
\hline fabploa & 171481 & TTACGCTCAGGAGAACTACG & СTTCCTGATCATGGTGGTTC & 55.0 \\
\hline fabplob & 795210 & CGGCTCCAGAGCACTACATC & GTTCACTCATGTGCGGGAGC & 60.0 \\
\hline fabpl1a & 447944 & TGTGCAGAAACAGACCTGGGA & ACAGCCACCACATCACCCATCTT & 60.0 \\
\hline fabp11b & 553579 & GCTGTCACTACATTCAAGACCTG & AGTTACCATCCGCAAGGCTCA & 60.0 \\
\hline acox 1 & 449662 & AGTCAGCACGAGCTCTCTCC & GCCCTACAAAGTGAAAGGCA & 58.0 \\
\hline$r p / 13 a$ & 560828 & AGCAAGTGCTGTTGGGCCAC & GTGTGGCGGTGATGGCCTGG & 61.0 \\
\hline \multicolumn{5}{|c|}{ hnRNA quantification } \\
\hline fabpla & 791610 & ATCAATGGAGGTCAACGGCGAC & CAGCATGCGTGAAGCCGCCC & 62.5 \\
\hline fabp $1 b .1$ & 554095 & GAACTAACGTGTGCTGCTTGTG & CACGTTTGCTGATGCGCTTGTA & 57.0 \\
\hline fabp $7 a$ & 58128 & CCATCCATCAGATTTCTATGTGGG & CATTATGCCTTCTCGTATGTGCG & 56.5 \\
\hline fabp $7 b$ & 407736 & TTGGAAATGTGACCAAACCGACGC & TCGTCTCGAAAGGGAATGCAGTGT & 61.5 \\
\hline fabploa & 171481 & TCCAGCAGAACGGCAGCGAC & CGCCTGTAAAGTGAAGCCATTTCCA & 61.0 \\
\hline fabp 11a & 447944 & CCAAGCCGTITTGATGATGTGAG & GCTATTAATTTCCCATCCGACACC & 57.0 \\
\hline acox 1 & 449662 & GGCTACTCCCGCTGCAGCAG & GGCCTGAGGGTTGTTGGGCC & 63.0 \\
\hline$r p / 13 a$ & 560828 & ACCAACCCTTCCCGTGGACCA & AGCCAATGCTTGCTTCTACAACAGA & 61.5 \\
\hline
\end{tabular}

${ }^{\mathrm{a}} \mathrm{AT}$, annealing temperature $\left({ }^{\circ} \mathrm{C}\right)$. 


\section{Statistical analysis}

Statistical analyses were performed using the GraphPad PRISM $^{\circledR}$ software version-5 (San Diego, California, USA). Data were analyzed using one-way analysis of variance (ANOVA). Post hoc comparisons were conducted using the Tukey's Multiple Comparison Test. The level of significance was chosen at $p<0.05$ and the results were presented as means \pm S.E.M.

\section{Abbreviations}

DDC: Duplication-degeneration-complementation; WGD: Whole genome duplication; FAs: Fatty acids; hnRNA: Heterogenous nuclear RNA; FABP: Mammal fatty acid-binding protein; FABP: Mammal fatty acid-binding protein gene; Fabp: Fish fatty acid-binding protein; Fabp: Fish fatty acidbinding protein gene; PPAR: Peroxisome proliferator-activated receptor; PPRE: Peroxisome proliferator response element; RT-qPCR: Reverse transcription-quantitative polymerase chain reaction.

\section{Competing interest}

The authors declare that they have no competing interests.

\section{Author's contributions}

ABV and JMW conceived and designed the studies. ABV carried out the experimental work and statistical analysis. SPL assisted in the formulation of zebrafish diet. EMD-W assisted in design and interpretation of RT-qPCR analysis. ABV and JMW drafted the manuscript. All authors read and approved the final version of the manuscript.

\section{Acknowledgments}

We thank Valarmathy Kaliaperumal for technical assistance during fish dissection and RNA isolation, Zhiyuan Lu for preparing the electron microscopy slides, and Sean Tibbets for help in preparation of diets fed zebrafish. This work was supported by funds from the Natural Sciences and Engineering Research Council of Canada (to JMW), National Research Council of Canada (to SPL), Canadian Institutes of Health Research and the Nova Scotia Health Research Foundation (to EMD-W). ABV is a recipient of a Faculty of Graduate Studies Scholarship from Dalhousie University.

\section{Author details}

'Department of Biology, Dalhousie University, Halifax, NS B3H 4R2, Canada. ${ }^{2}$ National Research Council of Canada, Institute of Marine Biosciences, Halifax, NS B3H 3Z1, Canada. ${ }^{3}$ Department of Pharmacology, Dalhousie University, Halifax, NS B3H 4R2, Canada.

Received: 2 February 2012 Accepted: 31 May 2012

Published: 9 July 2012

\section{References}

1. Ohno S: Evolution by Gene Duplication. New York (NY): Springer; 1970.

2. Holland PW, Garcia-Fernandez J, Williams NA, Sidow A: Gene duplications and the origins of vertebrate development. Dev Supp/ 1994, :125-133.

3. Sidow A: Gen(om)e duplications in the evolution of early vertebrates. Curr Opin Genet Dev 1996, 6:715-722.

4. Robinson-Rechavi M, Marchand O, Escriva H, Bardet PL, Zelus D, Hughes S, Laudet $\mathrm{V}$ : Euteleost fish genomes are characterized by expansion of gene families. Genome Res 2001, 11:781-788.

5. Taylor JS, Raes J: Duplication and divergence: the evolution of new genes and old ideas. Annu Rev Genet 2004, 38:615-643.

6. Force A, Lynch M, Pickett FB, Amores A, Yan YL, Postlethwait J: Preservation of duplicate genes by complementary, degenerative mutations. Genetics 1999, 151:1531-1545.

7. Lynch M, Conery JS: The evolutionary fate and consequences of duplicate genes. Science 2000, 290:1151-1155.

8. Bernlohr DA, Simpson MA, Hertzel AV, Banaszak LJ: Intracellular lipidbinding proteins and their genes. Annu Rev Nutr 1997, 17:277-303.

9. Schaap FG, van der Vusse GJ, Glatz JFC: Evolution of the family of intracellular lipid-binding proteins in vertebrates. Mol Cell Biochem 2002, 239:69-77.
10. Haunerland $\mathrm{NH}$, Spener F: Fatty acid-binding proteins - insights from genetic manipulations. Prog Lipid Res 2004, 43:328-349.

11. Wolfrum C: Cytoplasmic fatty acid-binding protein sensing fatty acids for peroxisome proliferator activated receptor activation. Cell Mol Life Sci 2007, 64:2465-2467.

12. Storch J, Corsico B: The emerging functions and mechanisms of mammalian fatty acid-binding proteins. Annu Rev Nutr 2008, 28:73-95.

13. Furlong RF, Holland PWH: Were vertebrates octoploid? Philos Trans $R$ Soc Lond B Biol Sci 2002, 357:531-544.

14. Jaillon O, Aury JM, Brunet F, Petit JL, Stange-Thomann N, Mauceli E, Bouneau L, Fischer C, Ozouf-Costaz C, Bernot A, Nicaud S, Jaffe D, Fisher S, Lutfalla G, Dossat C, Segurens B, Dasilva C, Salanoubat M, Levy M, Boudet N, Castellano S, Anthouard V, Jubin C, Castelli V, Katinka M, Vacherie B, Biémont C, Skalli Z, Cattolico L, Poulain J, de Berardinis V, Cruaud C, Duprat S, Brottier P, Coutanceau JP, Gouzy J, Parra G, Lardier G, Chapple C, McKernan KJ, McEwan P, Bosak S, Kellis M, Volff JN, Guigó R, Zody MC, Mesirov J, Lindblad-Toh K, Birren B, Nusbaum C, Kahn D, Robinson-Rechavi M, Laudet V, Schachter V, Quétier F, Saurin W, Scarpelli C, Wincker P, Lander ES, Weissenbach J, Roest Crollius H: Genome duplication in the teleost fish Tetraodon nigroviridis reveals the early vertebrate protokaryotype. Nature 2004, 431:946-957.

15. Woods IG, Kelly PD, Chu F, Ngo-Hazelett P, Yan Y-L, Huang H, Postlethwait $\mathrm{JH}$, Talbot WS: A comparative map of the zebrafish genome. Genome Res 2000, 10:1903-1914

16. Christoffels A, Koh EG, Chia JM, Brenner S, Aparicio S, Venkatesh B: Fugu genome analysis provides evidence for a whole-genome duplication early during the evolution of ray-finned fishes. Mol Biol Evol 2004, 21:1146-1151.

17. Vandepoele K, De Vos W, Taylor JS, Meyer A, Van de Peer Y: Major events in the genome evolution of vertebrates: Paranome age and size differ considerably between ray-finned fishes and land vertebrates. PNAS 2004, 101:1638-1643.

18. Denovan-Wright EM, Pierce M, Wright JM: Nucleotide sequence of CDNA clones coding for a brain-type fatty acid-binding protein and its tissue-specific expression in adult zebrafish (Danio rerio). Biochim Biophys Acta - Gene Struct Expr 2000, 1492:221-226.

19. Denovan-Wright EM, Pierce M, Sharma MK, Wright JM: CDNA sequence and tissue-specific expression of a basic liver-type fatty acid-binding protein in adult zebrafish (Danio rerio). Biochim Biophys Acta - Gene Struct Expr 2000, 1492:227-232

20. Pierce $M$, Wang YM, Denovan-Wright EM, Wright JM: Nucleotide sequence of a cDNA clone coding for an intestinal-type fatty acid binding protein and its tissue-specific expression in zebrafish (Danio rerio). Biochim Biophys Acta - Gene Struct Expr 2000, 1490:175-183.

21. Liu RZ, Denovan-Wright EM, Wright JM: Structure, mRNA expression and linkage mapping of the brain-type fatty acid-binding protein gene (fabp7) from zebrafish (Danio rerio). Eur J Biochem 2003, 270:715-725.

22. Liu RZ, Denovan-Wright EM, Wright JM: Structure, linkage mapping and expression of the heart-type fatty acid-binding protein gene (fabp3) from zebrafish (Danio rerio). Eur J Biochem 2003, 270:3223-3234.

23. Liu RZ, Denovan-Wright EM, Degrave A, Thisse C, Thisse B, Wright JM: Differential expression of duplicated genes for brain-type fatty acid-binding proteins ( $f a b p 7 a$ and $f a b p 7 b$ ) during early development of the CNS in zebrafish (Danio rerio). Gene Expr Patterns 2004, 4:379-387.

24. Sharma MK, Denovan-Wright EM, Degrave A, Thisse C, Thisse B, Wright JM: Sequence, linkage mapping and early developmental expression of the intestinal-type fatty acid-binding protein gene (fabp2) from zebrafish (Danio rerio). Comp Biochem Physiol B Biochem Mol Biol 2004, 138:391-398.

25. Sharma MK, Liu RZ, Thisse C, Thisse B, Denovan-Wright EM, Wright JM: Hierarchical subfunctionalization of fabp $1 a$, fabp $1 b$ and fabp 10 tissue-specific expression may account for retention of these duplicated genes in the zebrafish (Danio rerio) genome. FEBS J 2006, 273:3216-3229.

26. Liu RZ, Saxena V, Sharma MK, Thisse C, Thisse B, Denovan-Wright EM, Wright JM: The fabp4 gene of zebrafish (Danio rerio) - genomic homology with the mammalian FABP4 and divergence from the zebrafish fabp3 in developmental expression. FEBS J 2007, 274:1621-1633.

27. Alves-Costa FA, Denovan-Wright EM, Thisse C, Thisse B, Wright JM: Spatio-temporal distribution of fatty acid-binding protein 6 (fabp6) gene transcripts in the developing and adult zebrafish (Danio rerio). FEBS $J$ 2008, 275:3325-3334. 
28. Karanth S, Denovan-Wright EM, Thisse C, Thisse B, Wright JM: The evolutionary relationship between the duplicated copies of the zebrafish fabp 11 gene and the tetrapod FABP4, FABP5, FABP8 and FABP9 genes. FEBS J 2008, 275:3031-3040.

29. Venkatachalam AB, Thisse $C$, Thisse B, Wright JM: Differential tissue-specific distribution of transcripts for the duplicated fatty acid-binding protein 10 (fabp10) genes in embryos, larvae and adult zebrafish (Danio rerio). FEBS J 2009, 276:6787-6797.

30. Karanth S, Denovan-Wright EM, Thisse C, Thisse B, Wright JM: Tandem duplication of the fabp1b gene and subsequent divergence of the tissue-specific distribution of fabp 16.1 and fabp $1 b .2$ transcripts in zebrafish (Danio rerio). Genome 2009, 52:985-992.

31. Postlethwait JH, Woods IG, Ngo-Hazelett P, Yan YL, Kelly PD, Chu F, Huang $\mathrm{H}$, Hill-Force A, Talbot WS: Zebrafish comparative genomics and the origins of vertebrate chromosomes. Genome Res 2000, 10:1890-1902.

32. Woods IG, Wilson C, Friedlander B, Chang P, Reyes DK, Nix R, Kelly PD, Chu F, Postlethwait JH, Talbot WS: The zebrafish gene map defines ancestral vertebrate chromosomes. Genome Res 2005, 15:1307-1314

33. Hertzel AV, Bernlohr DA: The mammalian fatty acid-binding protein multigene family: molecular and genetic insights into function. Trends Endocrinol Metab 2000, 11:175-180.

34. Glatz JF, van der Vusse GJ: Cellular fatty acid-binding proteins: their function and physiological significance. Prog Lipid Res 1996, 35:243-282.

35. Ong DE, Newcomer ME, Chytil F: The Retinoids: Biology, Chemistry and Medicine. In Cellular retinoid-binding proteins. 2nd edition. Edited by Sporn MB, Roberts AB, Goodman DS. New York: Raven; 1994:283-317.

36. Wu Q, Andolfatto $\mathrm{P}$, Haunerland $\mathrm{NH}$ : Cloning and sequence of the gene encoding the muscle fatty acid binding protein from the desert locust, Schistocerca gregaria. Insect Biochem Mol Biol 2001, 31:553-562.

37. Parmar MB, Venkatachalam $A B$, Wright JM: The evolutionary relationship of the transcriptionally active fabp $11 a$ (intron less) and fabp $11 b$ genes of medaka with fabp11 genes of other teleost fishes. FEBS J 2012, 279:2310 2321.

38. Ong DE: Cellular transport and metabolism of vitamin A: roles of the cellular retinoid-binding proteins. Nutr Rev 1994, 52:S24-31.

39. Veerkamp JH, Maatman RG: Cytoplasmic fatty acid-binding proteins: thei structure and genes. Prog Lipid Res 1995, 34:17-52.

40. Zimmerman AW, Veerkamp JH: New insights into the structure and function of fatty acid binding proteins. Cell Mol Life Sci 2002, 11:1096-1116.

41. Leaver MJ, Boukouvala E, Antonopoulou E, Diez A, Favre-Krey L, Ezaz MT, Bautista JM, Tocher DR, Krey G: Three peroxisome proliferators activated receptor isotypes from each of two species of marine fish. Endocrinology 2005, 146:3150-3162.

42. Meunier-Durmort C, Poirier H, Niot I, Forest C, Besnard P: Up-regulation of the expression of the gene for liver fatty acid-binding protein by longchain fatty acids. Biochem J 1996, 319:483-487.

43. Poirier $H$, Niot I, Monnot MC, Braissant O, Meunier-Durmort C, Costet $P$, Pineau T, Wahli W, Willson TM, Besnard P: Differential involvement of peroxisome proliferator-activated receptors $a$ and $\delta$ in fibrate and fatty-acid-mediated inductions of the gene encoding liver fatty acidbinding protein in the liver and the small intestine. Biochem J 2001, 355:481-488.

44. Wu Q, Haunerland $\mathrm{NH}$ : A novel fatty acid response element controls the expression of the flight muscle FABP gene of the desert locust, Schistocerca gregaria. Eur J Biochem 2001, 268:5894-5900.

45. Qu H, Cui L, Haunerland JR, Haunerland NH: Fatty acid-dependent expression of the muscle FABP gene - comparative analysis of gene control in functionally related, but evolutionary distant animal systems. Mol Cell Biochem 2007, 299:45-53.

46. Schachtrup C, Emmler T, Bleck B, Sandqvist A, Spener F: Functional analysis of peroxisome-proliferator-responsive element motifs in genes of fatty acid-binding proteins. Biochem J 2004, 382:239-245.

47. Her GM, Yeh YH, Wu JL: 435-bp liver regulatory sequence in the liver fatty acid binding protein (L-FABP) gene is sufficient to modulate liver regional expression in transgenic zebrafish. Dev Dyn 2003, 227:347-356.

48. Her GM, Yeh YH, Wu JL: Functional conserved elements mediate intestinal-type fatty acid binding protein (I-FABP) expression in the gut epithelia of zebrafish larvae. Dev Dyn 2004, 230:734-742.

49. Karanth S, Lall SP, Denovan-Wright EM, Wright JM: Differential transcriptional modulation of duplicated fatty acid-binding protein genes by dietary fatty acids in zebrafish (Danio rerio): evidence for subfunctionalization and neofunctionalization of duplicated genes. BMC Evol Bio/ 2009, 9:219.

50. Yamoto T, Ohashi Y, Furukawa T, Teranishi M, Manabe S, Makita T: Change of the sex-dependent response to clofibrate in F344 rat liver during postnatal development. Toxicol Lett 1996, 85:77-83.

51. Haasch ML, Henderson MC, Buhler DR: Induction of lauric acid hydroxylase activity in catfish and bluegill by peroxisome proliferating agents. Comp Biochem Physiol C Pharmacol Toxicol Endocrinol 1998, 121:297-303.

52. Akbiyik F, Cinar K, Demirpence E, Ozsullu T, Tunca R, Haziroglu R, Yurdaydin C, Uzunalimoglu O, Bozkaya H: Ligand-induced expression of peroxisome proliferator-activated receptor alpha and activation of fatty acid oxidation enzymes in fatty liver. Eur J Clin Invest 2004, 34:429-435.

53. Nunes B, Carvalho F, Guilhermino L: Acute and chronic effects of clofibrate and clofibric acid on the enzymes acetylcholinesterase, lactate dehydrogenase and catalase of the mosquitofish, Gambusia holbrooki. Chemosphere 2004, 57:1581-1589.

54. Konig B, Kluge H, Haase K, Brandsch C, Stangl Gl, Eder K: Effects of clofibrate treatment in laying hens. Poult Sci 2007, 86:1187-1195.

55. Luci S, Giemsa B, Kluge H, Eder K: Clofibrate causes an upregulation of PPAR-a target genes but does not alter expression of SREBP target genes in liver and adipose tissue of pigs. Am J Physiol Regul Integr Comp Physiol 2007, 293:R70-R77.

56. Ringseis R, Posel S, Hirche F, Eder K: Treatment with pharmacological peroxisome proliferator-activated receptor a agonist clofibrate causes upregulation of organic cation transporter 2 in liver and small intestine of rats. Pharmacol Res 2007, 56:175-183.

57. Rorvik KA, Alne H, Gaarder M, Ruyter B, Maseide NP, Jakobsen JV, Berge RK, Sigholt T, Thomassen MS: Does the capacity for energy utilization affect the survival of post-smolt atlantic salmon, Salmo salar L., during natural outbreaks of infectious pancreatic necrosis. J Fish Dis 2007, 30:399-409.

58. Hess R, Staubli W, Riess W: Nature of the hepatomegalic effect produced by ethyl-chlorophenoxy-isobutylate in the rat. Nature 1965, 208:856-858

59. Svoboda DJ, Azarnoff DL: Response of hepatic microbodies to a hypolipidemic agent, ethyl chlorophenoxy isobutyrate (CPIB). J Cell Biol 1966, 30:442-450.

60. Lazarow PB, de Duve C: A fatty acyl-CoA oxidizing system in rat liver peroxisomes; enhancement by clofibrate, a hypolipidemic drug. Proc Natl Acad Sci USA 1976, 73:2043-2046.

61. Alvares K, Carrillo A, Yuan PM, Kawano H, Morimoto RI, Reddy JK: Identification of cytosolic peroxisome proliferator binding protein as a member of the heat shock protein HSP70 family. Proc Natl Acad Sci USA 1990, 87:5293-5297.

62. Tanaka K, Smith PF, Stromberg PC, Eydelloth RS, Herold EG, Grossman SJ, Frank JD, Hertzog PR, Soper KA, Keenan KP: Studies of early hepatocellular proliferation and peroxisomal proliferation in Sprague-Dawley rats treated with tumorigenic doses of clofibrate. Toxicol Appl Pharmacol 1992, 116:71-77.

63. Donohue M, Baldwin LA, Leonard DA, Kostecki PT, Calabrese J: Effect of hypolipidemic drugs gemfibrozil, ciprofibrate, and clofibric acid on peroxisomal beta-oxidation in primary cultures of rainbow trout hepatocytes. Ecotoxicol Environ Saf 1993, 26:127-132.

64. Paul HS, Sekas G, Winters SJ: Role of testosterone in the induction of hepatic peroxisome proliferation by clofibrate. Metabolism 1994, 43:168-173.

65. Ibabe A, Herrero A, Cajaraville MP: Modulation of peroxisome proliferator-activated receptors (PPARs) by PPARa- and PPARY- specific ligands and by $17 \beta$-estradiol in isolated zebrafish hepatocytes. Toxicol In Vitro 2005, 19:725-735

66. Mizumoto K, Kitazawa S, Eguchi T, Nakajima A, Tsutsumi M, Ito S, Danda A, Konishi Y: Modulation of $\mathrm{N}$-nitrosobis (2-hydroxypropyl) amine-induced carcinogenesis by clofibrate in hamsters. Carcinogenesis 1988, 9:1421-1425.

67. Holden PR, Tugwood JD: Peroxisome proliferator-activated receptor alpha: role in rodent liver cancer and species differences. $J$ Mol Endocrinol 1999, 22:1-8.

68. Pretti C, Novi S, Longo V, Gervasi PG: Effect of clofibrate, a peroxisome proliferator, in sea bass (Dicentrarchus labrax), a marine fish. Environ Res 1999, 80:294-296.

69. Lundgren B, Bergstrand A, Karlsson K, DePierre JW: Effects of dietary treatment with clofibrate, nafenopin or WY-14.643 on mitochondria and DNA in mouse liver. Biochim Biophys Acta 1990, 1035:132-138.

70. Meijer J, Starkerud C, Grandell I, Afzelius BA: Time-dependent effects of the hypolipidemic agentclofibrate on peroxisomes and mitochondria in mouse hepatocytes. J Submicroscop Cytol Pathol 1991, 23:185-194. 
71. Eagles DA, Chapman GB: A light- and electron-microscope study of hepatocytes of rats fed different diets. C R Biol 2007, 330:62-70.

72. Reddy JK, Hashimoto T: Peroxisomal $\beta$-oxidation and peroxisome proliferator-activated receptor a: an adaptive metabolic system. Annu Rev Nutr 2001, 21:193-230.

73. Helledie T, Grøntved L, Jensen SS, Kiilerich P, Rietveld L, Albrektsen T, Boysen MS, Nøhr J, Larsen LK, Fleckner J, Stunnenberg HG, Kristiansen K, Mandrup S: The gene encoding the Acyl-CoA-binding protein is activated by peroxisome proliferator-activated receptor gamma through an intronic response element functionally conserved between humans and rodents. J Biol Chem 2002, 277:26821-26830.

74. Watson JD, Baker TA, Bell SP, Gann A, Levine M, Losick R: Molecular Biology of the Gene. Cold Spring Harbor, NY: Pearson Benjamin Cummings/Cold Spring Harbor Laboratory Press; 2008:415-421.

75. Colton HM, Falls JG, Ni H, Kwanyuen P, Creech D, McNeil E, Casey WM, Hamilton G, Cariello NF: Visualization and quantitation of peroxisomes using fluorescent nanocrystals: treatment of rats and monkeys with fibrates and detection in the liver. Toxicol Sci 2004, 80:183-192.

76. Ockner RK, Manning JA: Fatty acid-binding protein in small intestine. Identification, isolation, and evidence for its role in cellular fatty acid transport. J Clin Invest 1974, 54:326-338.

77. Bass NM, Manning JA, Ockner RK, Gordon Jl, Seetharam S, Alpers DH: Regulation of the biosynthesis of 2 distinct fatty acid-binding proteins in rat-liver and intestine - influences of sex difference and of clofibrate. J Biol Chem 1985, 260:1432-1436.

78. Reddy JK: Peroxisome proliferators and peroxisome proliferator-activated receptor alpha: biotic and xenobiotic sensing. Am J Pathol 2004 164:2305-2321.

79. Mochizuki K, Mochizuki H, Kawai H, Ogura Y, Shmada M, Takase S, Goda T: Possible role of fatty acids in milk as the regulator of the expression of cytosolic binding proteins for fatty acids and vitamin A through PPAR alpha in developing rats. J Nutr Sci Vitaminol 2007, 53:515-521.

80. Schroeder F, Petrescu AD, Huang H, Atshaves BP, Mclntosh AL, Martin GG, Hostetler HA, Vespa A, Landrock D, Landrock KK: Role of fatty acid binding proteins and long chain fatty acids in modulating nuclear receptors and gene transcription. Lipids 2008, 43:1-17.

81. Huang $H$, Starodub $O$, Mclntosh A, Atshaves BP, Woldegiorgis G, Kier AB, Schroeder F: Liver fatty acid-binding protein colocalizes with peroxisome proliferator activated receptor alpha and enhances ligand distribution to nuclei of living cells. Biochemistry 2004, 43:2484-2500.

82. Delva L, Bastie JN, Rochette-Egly C, Kraiba R, Balitrand N, Despouy G, Chambon P, Chomienne C: Physical and functional interactions between cellular retinoic acid binding protein II and the retinoic acid-dependent nuclear complex. Mol Cell Biochem 1999, 19:7158-7167.

83. Budhu AS, Noy N: Direct channelling of retinoic acid between cellular retinoic acid binding protein II and retinoic acid receptor sensitizes mammary carcinoma cells to retinoic acid induced growth arrest. Mol Cell Biochem 2002, 22:2632-2641.

84. Tan NS, Shaw NS, Vinckenbosch N, Liu P, Yasmin R, Desvergne B, Wahli W, Noy N: Selective cooperation between fatty acid binding proteins and peroxisome proliferator activated receptors in regulating transcription. Mol Cell Biochem 2002, 22:5114-5127.

85. Gottlicher M, Widmark E, Li Q, Gustafsson JA: Fatty acids activate a chimera of the clofibric acid-activated receptor and the glucocorticoid receptor. Proc Natl Acad Sci USA 1992, 89:4653-4657.

86. Keller H, Dreyer C, Medin J, Mahfoudi A, Ozato K, Wahli W: Fatty acids and retinoids control lipid metabolism through activation of peroxisome proliferator-activated receptorretinoid X receptor heterodimers. Proc Natl. Acad Sci USA 1993, 90:2160-2164

87. Lemberger T, Desvergne B, Wahli W: Peroxisome proliferator-activated receptors: a nuclear receptor signalling pathway in lipid physiology. Annu Rev Cell Dev Biol 1996, 12:335-363.

88. Desvergne $\mathrm{B}$, Wahli W: Peroxisome proliferator-activated receptors: nuclear control of metabolism. Endocr Rev 1999, 20:649-688.

89. Escher $P$, Wahli W: Peroxisome proliferator activated receptors: insights into multiple cellular functions. Mutat Res 2000, 448:121-138.

90. Wolfrum C, Borrmann CM, Borchers T, Spener F: Fatty acids and hypolipidemic drugs regulate PPARa and PPARY gene expression via L-FABP: a signaling path to the nucleus. Proc Natl Acad Sci USA 2001, 98:2323-2328.
91. Wilk BK, Kiec AD, Olszanecka A, Bodzioch M, Kawecka-Jaszcz K: The selected pathophysiological aspects of PPARs activation. J Physiol Pharmacol 2005, 56:149-162.

92. Kaikaus RM, Chan WK, de Ortiz Montellano PR, Bass NM: Mechanisms of regulation of liver fatty acid-binding protein. Mol Cell Biochem 1993, 123:93-100.

93. Wolfrum C, Ellinghaus P, Fobker M, Seedorf U, Assmann G, Börchers T, Spener F: Phytanic acid is ligand and transcriptional activator of murine liver fatty acid binding protein. J Lipid Res 1999, 40:708-714.

94. Hansmannel F, Clémencet MC, Le Jossic-Corcos C, Osumi T, Latruffe N, Nicolas-Francés V: Functional characterization of a peroxisome proliferator response-element located in the intron 3 of rat peroxisomal thiolase B gene. Biochem Biophys Res Commun 2003, 311:149-155.

95. National Research Council: Nutrient Requirements of Fish. Washington DC: The National Academies Press; 1993.

96. Goolish EM, Okutake K, Lesure S: Growth and survivorship of larval zebrafish (Danio rerio) on processed diets. N Am J Aquacult 1999, 61:189-198.

97. Meinelt T, Schulz C, Wirth M, Kuerzinger H, Steinberg C: Dietary fatty acid composition influences the fertilization rate of zebrafish (Danio rerio). $J$ Appl Ichthyol 1999, 15:19-23.

98. Bradford Y, Conlin T, Dunn N, Fashena D, Frazer K, Howe DG, Knight J, Mani P, Martin R, Moxon SA, Paddock H, Pich C, Ramachandran S, Ruef BJ, Ruzicka L, Bauer Schaper H, Schaper K, Shao X, Singer A, Sprague J, Sprunger B, Van Slyke C, Westerfield M: ZFIN: enhancements and updates to the zebrafish model organism database. Nucleic Acids Res 2011, 39:D822-829.

99. Westerfield M: The Zebrafish Book: A Guide for the Laboratory Use of Zebrafish (Danio rerio). Eugene (OR): University of Oregon Press; 2000.

100. Saito Y, Tanaka Y: Glutaraldehyde fixation of fish tissues for electron microscopy. J Electron Microsc 1980, 29:1-7.

101. Bozzola JJ, Russell LD: Electron Microscopy: Principles and Techniques for Biologists. Sudbury (MA): Jones and Bartlett Publishers; 1999.

102. Luft JH: Improvements in epoxy resin embedding methods. J Biophys Biochem Cytol 1961, 9:409-414.

103. Bustin SA, Benes V, Nolan T, Pfaffl MW: Quantitative real-time RT-PCR - a perspective. J Mol Endocrinol 2005, 34:597-601.

104. Tang R, Dodd A, Lai D, McNabb WC, Love DR: Validation of zebrafish (Danio rerio) reference genes for quantitative real-time RT-PCR normalization. Acta Biochim Biophys Sin 2007, 39:384-390.

doi:10.1186/1471-2148-12-112

Cite this article as: Venkatachalam et al.: Tissue-specific differential induction of duplicated fatty acid-binding protein genes by the peroxisome proliferator, clofibrate, in zebrafish (Danio rerio). BMC Evolutionary Biology 2012 12:112.

\section{Submit your next manuscript to BioMed Central and take full advantage of:}

- Convenient online submission

- Thorough peer review

- No space constraints or color figure charges

- Immediate publication on acceptance

- Inclusion in PubMed, CAS, Scopus and Google Scholar

- Research which is freely available for redistribution 